\title{
PREDIKTOR PERILAKU PEMILIH PADA PEMILUKADA: Perspektif Psikologi Politik
}

\author{
M. Daud \\ Fakultas Psikologi Universitas Negeri Makassar \\ Email: daoed64@yahoo.com
}

\begin{abstract}
Local election democracy has been instrumental in increasing the political partaicipation of society, to obtain local leaders who are elected democratically. Local election as mechanisms of local democracy in Indonesia, have an impact on voter behavior tendencies. This study aims to discuss the essence of the local election in the dynamics of local politics and democracy as well as its relationship with the trend of voter behavior. Based on the various theories and research, found that voting behavior is influenced by many factors, including sociological factors, psychological factors, economic factors and factors of mass media. These factors apparently also found in the implementation of the General Election in Indonesia and partaicularly in South Sulawesi.
\end{abstract}

Key words: voters behavior, local election, political psychology

\begin{abstract}
Abstrak
Pemilukada telah menjadi instrument demokrasi dalam meningkatkan partaisipasi politik masyarakat, untuk memperoleh pemimpin lokal yang terpilih secara demokratis. Pemilukada sebagai mekanisme demokrasi lokal di Indonesia, telah memberi dampak terhadap kecenderungan perilaku pemilih. Kajian ini bertujuan untuk membahas esensi Pemilukada dalam dinamika politik dan demokrasi lokal serta hubungannya dengan kecenderungan perilaku pemilih. Berdasarkan pelbagai teori dan hasil penelitian, ditemukan bahawa perilaku pemilih dipengaruhi oleh banyak faktor, diantaranya faktor sosiologi, faktor psikologi, faktor ekonomi dan faktor media massa. Faktor-faktor tersebut tampaknya juga ditemukan pada pelaksanaan Pemilukada di Indonesia dan khususnya di Sulawesi Selatan.
\end{abstract}

Kata-kata kunci: perilaku pemilih, pemilukada, psikologi politik

$\mathrm{B}$ ergulirnya iklim reformasi membawa berkah tersendiri dalam proses demokrasi di Indonesia. Alam reformasi meniscayakan sistem demokrasi dalam praktik kehidupan berpolitik, yang hampir setengah abad mengalami ketertutupan begitu luar biasa. Persoalannya, adalah apakah iklim reformasi berdampak dalam peningkatan pelayanan terhadap kepentingan masyarakat? atau sebaliknya, reformasi justru semakin menjauhkan kepentingan rakyat dari para pemimpinnya. Pertanyaan inipun mengemuka saat terlaksananya pemilihan kepala daerah
(Pilkada) langsung, sebuah mekanisme pemilihan langsung kepala daerah secara demokratis, yang merupakan berkah dari era reformasi.

Pilkada langsung yang dipraktikkan pertama kali pada 1 Juni 2005, merupakan turunan langsung dari mekanisme pemilihan Presiden secara langsung saat Pemilu 2004. Pada hakekatnya, Pilkada harus didefinisikan sebagai salah satu jenis partaisipasi rakyat dalam berkontribusi bagi perkembangan pemerintahan daerah ke arah yang lebih baik. Inilah sesungguhnya hakekat dari Pilkada, di 
satu sisi menjadi sarana demokratis penyampai aspirasi rakyat, dan sisi lain menjadi jalan bagi peningkatan kesejahteraan. Karenanya rakyat boleh berharap, Pilkada akan mampu memperbaiki taraf hidup dan kesejahteraan rakyat, sebagaimana janji-janji kampanye para calon pemimpin dan aktivis partai politik yang terkadang memekakkan gendang telinga.

Perjalanan demokrasi di Indonesia termasuk di Sulawesi Selatan semakin berwujud manifestasinya dalam bentuk pelaksanaan pemilukada secara langsung. Pemilukada diharapkan mampu mengurangi distorsi yang terjadi di masa lalu, saat pemilihan kepala daerah dilakukan oleh anggota parlemen (DPRD), baik pada pemilihan Gubernur maupun dalam pemilihan Bupati dan Walikota (Pigur, 2008).

Perjalanan pelaksanaan Pemilukada bisa dikatakan lancar, namun tercatat ada beberapa yang bermasalah, seperti pemilukada kota Depok, pemilukada di Sumatera, pemilukada Kalimantan, pemilukada di Jawa, pemilukada di Sulawesi, pemilukada NTT, Maluku, hingga Papua. Pemilukada di beberapa daerah tersebut telah membuat pertarungan bukan hanya di tingkat lokal, melainkan bergeser menjadi isu nasional. Hal itu disebabkan karena hasil pemilukada di daerah tersebut menimbulkan sengketa pemilukada antar calon dengan calon dan calon dengan KPUD selaku pelaksana pemilukada. Menurut Ryas Rasyid (Pigur, 2008) adanya kelemahan mendasar dalam perundangan-undangan no. 32/2004 sebagai penyebab terjadinya sengketa pemilukada.

Dalam kaitan itu, maka penulis menganggap perlunya analisis dan kajian mendalam secara psikologi, dan sosio-politik tentang perilaku politik masyarakat dalam pemilukada, dan menyikapi hasil pemilukada yang ditetapkan oleh KPU selaku pelaksana pemilukada.

\section{Pemilukada dan Perilaku Pemilih}

Masyarakat Indonesia termasuk cenderung pelupa dan mudah memaafkan. Janji-janji kampanye dalam Pemilukada yang mempengaruhi perilaku politik masyarakat, biasanya akan mengalir begitu saja, bahkan hilang menguap, ketika sang calon telah terpilih dan berkuasa. Persoalannya, kita tidak memiliki mekanisme yang tegas untuk memantau realisasi janji-janji kampanye, karena belum berkualitasnya pemilukada yang kita jalankan. Apakah hanya persoalan itu yang menganggu hakekat pemilukada demi kepentingan rakyat? jawapannya, tidak karena masih banyak persoalan lain. Persoalan yang terkait dengan peran pihak pelaksananya (KPUD dan Panwasda), aturan hukum yang belum tegas, menimbulkan interpretasi yang beragam sehingga muncul konflik sosial pasca penghitungan suara dan penetapan pemenang.

Di Indonesia, pemilihan umum merupakan sarana untuk memberikan kesempatan kepada rakyat untuk ikut serta mempengaruhi kebijakan pemerintah dan sistem politik yang berlaku. Jadi aktivitas pemilihan umum merupakan sarana partaisipasi politik rakyat. Selain itu, terdapat bentuk partaisipasi politik yang konvensional iaitu lobbying, sebagai kegiatan untuk mencari sokongan, penyebaran pengaruh, dan penyampaian usul-usul yang boleh dijadikan bahan pertimbangan dalam pengambilan keputusan.

Psikologi memandang perilaku manusia (human behavior) sebagai reaksi yang dapat bersifat sederhana maupun bersifat kompleks. Sikap selalu dikaitkan dengan perilaku yang berada dalam batas kewajaran dan kenormalan yang merupakan respon atau reaksi terhadap stimulus lingkungan sosial. Salah satu karakteristik reaksi perilaku manusia yang menarik adalah sifat diferensialnya. Maknanya, satu stimulus dapat menimbulkan lebih dari satu respon yang berbeda, dan beberapa stimulus dapat saja menimbulkan satu respon yang sama (Azwar, 2007). Akan tetapi sifat diferensial perilaku tidak banyak membantu dalam memahami variabel-variabel penyebab perilaku untuk meramalkan sesuatu perilaku.

Kurt Lewin, 1951 (dalam Brigman, 1991) merumuskan suatu model hubungan perilaku bahawa; perilaku (B) adalah fungsi karakteristik individu $(\mathrm{P})$ dan lingkungan $(\mathrm{E})$ iaitu: $B=f(P, E)$. Karakteristik individu meliputi 
pelbagai variabel seperti motif, nilai, sifat kepribadian, dan sikap yang saling berinteraksi satu sama lain, dan kemudian berinteraksi dengan faktor-faktor lingkungan dalam menentukan perilaku. Faktor lingkungan memiliki kekuatan besar dalam menentukan perilaku, bahkan kekuatannya kadang-kadang lebih besar daripada karakteristik individu (Azwar, 2007).

Dalam proses demokrasi, tingkah laku politik dipengaruhi oleh pelbagai sebab atau faktor, dan faktor-faktor tersebut mempengaruhi tingkah laku secara serentak. Sehingga sukar untuk menentukan faktor mana yang lebih penting dan dominan dalam mempengaruhi tingkah laku seseorang. Dalam pemilihan umum, sikap seseorang terhadap sesuatu partai politik atau calon memimpin begitu kuat mempengaruhi tingkah laku untuk memilihnya atau sebaliknya. Walau bagaimana pun apabila berlaku perubahan sikap, tingkah laku seseorang juga mungkin ikut berubah (Redzuan, 2001).

Selanjutnya, perilaku politik warga negara dalam bentuk partaisipasi politik oleh Milbrath (dalam Rush, Michel dan Altoff, 1989) dijelaskan dalam kaitan dengan empat faktor utama yaitu: 1) sejauh mana orang menerima peransang politik; 2) karakteristik pribadi seseorang; 3) karakteristik sosial seseorang; 4) keadaan politik atau lingkungan politik seseorang. Selain itu, terdapat dua variabel yang mempengaruhi partaisipasi politik warga negara biasa iaitu; kesadaran politik dan kepercayaan kepada pemerintah (sistem politik). Kedua variabel tersebut tidak berada pada kutub berlawanan, yang sekaligus menentukan sikap dan perilaku warga negara dalam perilaku politiknya, tetapi berada secara integral dengan faktor lain seperti; status sosial, status ekonomi, afiliasi politik, dan pengalaman berorganisasi.

Partaisipasi politik adalah keikutsertaan warga negara biasa dalam menentukan segala keputusan yang menyangkut atau mempengaruhi kehidupannya. Partaisipasi politik boleh dibedakan menjadi partaisipasi aktif dan partaisipasi pasif (Surbakti, 1992). Selain itu, partaisipasi politik juga boleh digolongkan sesuai dengan tingkatannya, yaitu; apatis, spektator dan gladiator (Milbrath \& Goel, dalam Surbakti, 1992). Bentuk partaisipasi politik masyarakat dapat dibedakan menjadi partaisipasi individual dan partaisipasi kolektif (N. Muller, dalam Surbakti, 1992).

Selanjutnya terdapat dua variabel yang mempengaruhi partaisipasi politik warga negara biasa, yaitu kesedaran politik dan kepercayaan pada pemerintah (sistem politik). Partaisipasi politik berdasarkan sifatnya dapat dibedakan menjadi partaisipasi bersifat sukarena (otonom) dan atas desakan orang lain (dimobilisasi). Dalam kaitan itu, Nelson membedakan dua sifat partaisipasi politik iaitu; autonomous partaicipation (partaisipasi otonom) dan mobilized partaicipation (partaisipasi yang dimobilisasikan) (Budiardjo 1982, Huntington 1994, dalam Almond, Gabriel dan Vebra 1991).

Sebagai manifestasi sikap politik, maka perilaku politik tidak dapat dipisahkan daripada budaya politik, yang oleh Almond dan Verba (1990) diartikan sebagai suatu sikap orientasi yang khas warga negara terhadap sistem politik dan aneka ragam bagiannya. Selanjutnya, dalam mengkaji perilaku politik seringkali dilakukan dari sudut pandangan psikologi, selain pendekatan struktural fungsional dan struktur konflik. Sudut pandang psikologis ini menjelaskan pertimbangan-pertimbangan latar belakang secara menyeluruh, baik aspek politik, ekonomi, sosial budaya, mahupun pertimbangan kepentingan lain.

\section{Prediktor perilaku pemilih}

Dalam perspektif psikologi, untuk memahami dan memprediksi (meramalkan) perilaku, maka Icek Ajzen dan Martin Fishbein, 1980 (dalam Ajzen 1988; Brehm dan Kassin, 1990; Redzuan, 2001; dan Azwar, 2007) mengemukakan Teori Tindakan Beralasan atau Munasabah (theory of reasoned action). Menurut teori ini, cara yang terbaik untuk meramalkan misalnya manusia akan melakukan sesuatu tingkah laku atau tidak adalah dengan 
menanyakan hasrat mereka bertingkah laku. Hasrat mencerminkan perancangan manusia untuk terlibat dalam sesuatu tingkah laku yang sesuai dengan sikap yang dianuti. Dengan demikian, perkara yang penting ialah faktor pemicu atau sebab yang mempengaruhi hasrat seseorang untuk bertingkah laku.

Perilaku politik adalah aktiviti yang berkenaan dengan proses pembuatan dan pelaksanaan keputusan politik berdasarkan sikap politik. Perilaku politik juga dimaknai dengan interaksi antar lembaga pemerintah, antara pemerintah dan masyarakat, antara kelompok dan individu dalam masyarakat dalam pembuatan, pelaksanaan, dan penegakan keputusan politik.

Perilaku politik merupakan salah satu aspek dari perilaku secara umum, karena disamping perilaku politik juga ada perilaku lain seperti perilaku ekonomi, perilaku budaya, perilaku keagamaan dan sebagainya. Perilaku politik merupakan perilaku yang menyangkut persoalan politik. Menurut Surbakti (1992) perilaku politik dapat dirumuskan sebagai kegiatan yang berkenaan dengan proses pembuatan dan pelaksanaan keputusan politik.

Perilaku politik berkenaan dengan tujuan suatu masyarakat, kebijakan untuk mencapai suatu tujuan, serta sistem kekuasaan yang memungkinkan adanya suatu otoritas untuk mengatur kehidupan masyarakat ke arah pencapain tujuan tersebut. Perilaku politik dapat dijumpai dalam pelbagai bentuk. Perilaku politik tidaklah merupakan sesuatu yang berdiri sendiri, karena terkait dengan hal-hal lainnya. Perilaku politik yang ditunjukkan oleh individu merupakan hasil pengaruh beberapa faktor, sama ada baik faktor internal maupun faktor eksternal, yang menyangkut lingkungan alam maupun lingkungan sosial budaya (Sastroatmodjo, 1995). Perilaku politik merupakan tindakan yang dilakukan oleh suatu subjek. Subjek dapat berupa pemerintah dan dapat juga masyarakat. Selain itu, subjek juga dapat berupa partai-partai politik yang ada.

Kajian perilaku politik dapat dilakukan dengan menggunakan tiga unit dasar analisis, yaitu individu sebagai aktor politik, agregasi politik, dan tipologi kepribadian politik (Sastroatmodjo, 1995). Perilaku individu sebagai aktor politik yang memiliki pengaruh dalam proses politik adalah pemimpin politik dan pemerintahan. Oleh karena itu, tipe pemimpin politik dan pemerintahan akan sangat mempengaruhi suasana kehidupan politik. Sedangkan agregasi politik adalah kelompok individu yang tergabung dalam suatu organisasi seperti partai politik, kelompok kepentingan, birokrasi dan lembaga-lembaga pemerintahan. Selanjutnya, tipologi kepribadian politik adalah tipe-tipe kepribadian pemimpin seperti pemimpin otoriter, pemimpin demokratis, dan leisessfeir.

Perilaku politik dapat berupa perilaku lembaga-lembaga politik dan perilaku politik individu. Perilaku politik lembaga dijalankan oleh lembaga politik yang terdiri daripada individu-individu pengerusi dan ahli partai politik sesuai tugas dan wewenang yang ada padanya, sedangkan perilaku politik invididu adalah perilaku politik yang dijalankan tiap individu (aktor politik) sebagai bentuk peran sertanya di dalam aktiviti dan peristiwa politik.

Berdasarkan uraian di atas, maka perilaku politik ialah keseluruhan aktivitas terencana yang berkenaan dengan persoalan politik, baik yang menyangkut proses pemilihan dan pembuatan keputusan maupun pelaksanaan keputusan politik. Perilaku politik tersebut berlaku pada masa pemilihan umum dan pemilihan kepala daerah untuk memilih calon Presiden, anggota Legislatif, Gubernur, Bupati dan Walikota.

Adapun prediktor atau faktor penentu perilaku politik adalah seluruh faktor-faktor yang dapat mempengaruhi dan mendorong terjadinya perilaku politik (Sastroatmodjo, 1995). Faktor-faktor tersebut mencakup; 1) lingkungan sosial politik langsung (keluarga, sekolah, lingkungan); 2) lingkungan sosial politik tak langsung (sistem politik, ekonomi, dan budaya); 3) struktur kepribadian; dan 4) faktor sosial politik langsung (situasi politik \& suasana kelompok). Faktor penentu perilaku politik lainnya adalah persekitaran alamiah, faktor internal, faktor eksternal dan persekitaran sosial-budaya. Selain faktor-faktor 
penentu tersebut, juga dikenal adanya tiga unit dasar dalam melakukan analisis perilaku politik iaitu; 1) individu sebagai aktor, 2) agregasi politik, dan 3) tipologi kepribadian politik.

Selanjutnya Newman dan Sheeth (1985) mengembangkan pendekatan baru sebagai model perilaku pemilih, berdasarkan beberapa domain yang berkait dengan pemasaran. Model ini dikembangkan untuk menerangkan, meramalkan dan memahami perilaku pemilih yang dikenal dengan model political pemasaran. Pendekatan ini membantu pemilih untuk memilih atau membeli calon yang 'dipasarkan' dalam pemilihan umum. Menurut model ini, perilaku pemilih ditentukan oleh tujuh domain kognitif yang berbeza dan terpisah, iaitu: (1) isu dan polisi (issues and policies), sebagai bahan kampanye yang dijanjikan yang diperjuangkan jika menjadi calon yang terpilih, (2) imej sosial (social imagery), sebagai kebolehan mencipta 'kedekatan sosial' atau 'keberadaan diri' calon/partai dengan masyarakat pemilih yang heterogen, (3) perasaan emosi (emotional feeling), sebagai kebolehan membangun kedekatan atau kelekatan emosional antara calon/partai dengan masyarakat pemilih, (4) imej calon (candidate personality), sebagai kebolehan membangun gambaran dan imej positif tentang diri calon/partai agar diterima di kalangan pemilih, (5) peristiwa-peristiwa mutakhir (current events), yang berkembang menjelang dan selama kampanye, (6) peristiwaperistiwa pribadi (personal events) berkaitan dengan kehidupan peribadi dan peristiwa yang pernah dialami seorang calon/partai, (7) isu-isu epistemik (epistemic issues), berkaitan isu spesifik/khusus yang memicu keingintahuan pemilih tentang hal-hal baharu. Model perilaku pemilih Newman dan Sheeth tersebut, juga telah menjadi variabel kajian para pengkaji perilaku pemilih pada pemilihan umum umum dan pemilihan umum kecil di Indonesia.

Variabel di atas, juga digunakan oleh Newman untuk meramalkan kecenderungan keputusan pemilih dalam pemilihan presiden Amerika Syarikat tahun 1996 (Newman 1999). Alasan digunakan model ini adalah sebagaimana yang dikemukakan oleh Newman (1999) karena adanya kecenderungan bahawa perseorangan dalam peranannya sebagai pemilih, selalu berusaha untuk melihat secara utuh calon. Variabel di atas juga sudah sering digunakan oleh beberapa pengkaji untuk mengetahui kecenderungan perilaku pemilih.

Adman Nursal (2004), juga menawarkan faktor-faktor yang mempengaruhi perilaku pemilih yang didasarkan pada penyederhanaan aliran-aliran sebelumnya yang meliputi: image sosial/pengelompokan sosial, identifikasi partai, calon (emotional feelings dan candidate personality), isu dan kebijakan politik, peristiwa tertentu (peristiwa muthakir dan peristiwa personal) dan epistemic issues.

Selain hal tersebut di atas, faktor lain yang dapat memengaruhi seseorang dalam memberikan suaranya atau mengambil undi ialah karakteristik sosial. Karakteristik sosial dan pengelompokan sosial memiliki pengaruh dalam menentukan perilaku memilih. Pengelompokan sosial seperti usia (tua-muda), jenis kelamin (lelaki-perempuan), agama dan semacamnya mempunyai peranan yang cukup menentukan dalam membentuk perilaku memilih (Dean Jaros 1974).

Selanjutnya, Campbel Angus dalam bukunya The American Voter (1976) mengemukakan faktor karakteristik sosial juga memiliki pengaruh terhadap kecenderungan seseorang dalam memilih pada pemilihan umum umum sebagai tindakan kelompok sosial, terdapat hubungan antara karakteristik sosial seseorang dengan perolehan undi yang didapatkan. Adapun karakteristik sosial yang mempengaruhi penglibatan politik dalam mengambil undi iaitu: pendidikan, pekerjaan, penghasilan, usia, jenis kelamin. Dengan demikian, jelas bahawa karakteristik sosial memiliki pengaruh terhadap seseorang dalam memberikan undinya pada partai politik atau calon partai.

Sementara itu, terdapat peneliti-peneliti lain baik yang berasal dari Eropa, Amerika, Asia dan khususnya Indonesia yang mengkaji perilaku pemilih, terutama faktor-faktor yang 
mempengaruhi keputusan memilih, antaranya, Berelson (1954), Cambell (1960), Rieker dan Ordenshook (1968), Butler dan Stoke (1969), Watanuki dalam La Palombara (1974), Ferejhon dan Fiorina (1974), Muller, Tollison, Willet (1976), Thomassen (1974) dan Kaase (1976) dalam Niemi (1984), Affan Gaffar (1988), J Kristiadi (1993) Muhammad Asfar (1997; 2004).

Pendekatan sosiologi atau lebih tepatnya disebut pendekatan sosial struktural untuk menerangkan perilaku memilih, secara logik terbahagi atas model penjelasan mikrososiologi dan model penjelasan makrososiologi. Model penjelasan mikrososiologi sentiasa dikaitkan dengan ahli sosiolog Paul F. Lazarsfeld, Bernard Berelson dan Hazel Graudet dari Columbia University (1944). Karena itu, model ini biasanya disebut mazhab atau model pendekatan Columbia (Columbia School). Sedangkan penjelasan makrososiologi dari Seymour Martin Lipset dan Stein Rokkan (1967), didasarkan atas pengamatan perilaku memilih menurut Lazarfeld. Model ini menelaah perilaku memilih di seluruh tahapan atau lapisan masyarakat secara keseluruhan (Roth 2008).

Dasar model pendekatan mikrososiologi berasal dari teori lingkaran sosial yang dirumuskan oleh George Simmel (1890). Menurut teori ini, setiap manusia terikat di dalam pelbagai lingkaran sosial, seperti keluarga, lingkaran rekan-rekan, lingkungan kerja dan sebagainya. Selanjutnya Paul F. Lazarsfeld $(1944 ;$ 1968) menerapkan cara berfikir ini terhadap para pemilih. Menurut Lazarsfeld, seorang pemilih hidup dalam konteks tertentu seperti status ekonominya, agamanya, tempat tinggalnya, pekerjaannya dan usianya didefinisikan sebagai lingkaran sosial yang mempengaruhi keputusan sang pemilih (Roth 2008).

Para peneliti yang mengacu kepada Lazarsfeld adalah ingin mengkaji perubahan pandangan politik dan motif mengikuti pemilihan umum, selama kampanye pemilihan umum bagi memilih presiden, pada kelompok pemilih yang suka berubah dan yang tetap. Perubahan perilaku memilih seseorang cenderung mengikuti arah kecenderungan politik persekitaran sosial perseorangan tersebut. Pengaruh terbesar berasal dari keluarga dan persekitaran rakan/sahabat karib perseorangan terkait. Selanjutnya untuk mempertegas fakta bahawa penentuan perilaku memilih seseorang berkaitan dengan hubungan sosial dari mana individu tersebut berasal, maka Columbia School mengembangkan suatu indeks kecenderungan politik, yang memiliki nilai perkiraan yang tinggi. Hasilnya indeks tersebut hanya terdiri atas kombinasi tiga faktor iaitu; status sosial ekonomi, agama dan kawasan tempat tinggal. Maknanya bahawa seseorang berfikir politik sebagaimana ia berfikir secara sosial, karena karakteristik sosial menentukan kecenderungan politis seseorang (Roth 2008; Agustino 2009).

Selanjutnya, model penjelasan makrososiologi dari Lipset dan Rokkan mengacu kepada konflik-konflik mendasar yang biasa muncul di masyarakat. Konflikkonflik tersebut boleh berkaitan dengan ekonomi antara majikan dengan golongan pekerja, konflik partai, dan konflik agama. Berangkat dari garis konvensional antara umat Katolik dengan Protestan, berkembanglah sebuah garis konflik keagamaan (Pappi 1985) iaitu konflik antara pemilih yang berorientasi keagamaan atau terikat kepada gereja dengan para pemilih yang tidak religius atau kurang memiliki ikatan keagamaan.

Model lifestyle atau gaya hidup yang berasal dari tinjauan pasar dan konsumsi yang diadakan awal tahun 80-an, kini masih ditawarkan sebagai dasar pemikiran dalam menjelaskan perilaku pemilih. Penentuan sosial struktural dari perilaku pemilih masih dapat diamati secara jelas hingga masa ini, seperti masyarakat yang memiliki mobilitas tinggi di Republik Federal Jerman sekarang ini. Biasanya penilaian status sosial struktural dilakukan dengan melihat keanggotaan seseorang dalam pelbagai kelompok profesion yang ada (Roth 2008).

Model pendekatan atau mazhab Columbia menekankan pada faktor sosiologi dalam membentuk perilaku masyarakat dalam menentukan pilihan pada pemilihan umum 
umum. Model ini melihat masyarakat sebagai satu kesatuan kelompok yang bersifat vertikal dari tahap yang terbawah hingga yang teratas. Penganut pendekatan ini percaya bahawa masyarakat terstruktur oleh norma-norma dasar sosial yang berdasarkan atas pengelompokan sosiologi seperti agama, kelas (status sosial), pekerjaan, usia, dan jenis kelamin dianggap mempunyai peranan yang cukup menentukan dalam membentuk perilaku pemilih. Oleh karena itu , dasar dan alasan pilihan terhadap suatu partai politik merupakan suatu produk dari karakteristik sosial individu yang bersangkutan (Afan Gaffar 1992).

Selanjutnya, ketika para peneliti pemilihan umum dari Columbia School lebih mengaitkan perilaku pemilih dengan konteks kemasyarakatan di mana perseorangan tersebut bernaung atau berada, maka sekelompok ahli ilmu sosial dari University of Michigan di Ann Arbor lebih menempatkan individu itu sendiri sebagai pusat perhatian mereka. Menurut Ann Arbor School (Roth 2008), persepsi dan penilaian peribadi terhadap calon atau tematema yang diangkat (pengaruh jangka pendek) sangat berpengaruh terhadap pilihannya pada pemilihan umum. Selain itu, 'keanggotaan psikologi' dalam sebuah partai yang dapat diukur dalam bentuk variable dentifikasi partai, turut mempengaruhi pilihan pada pemilihan kepala daerah, yang mana merupakan hasil pelbagai pengaruh jangka panjang. Oleh karena itu, keputusan pemilihan umum bagi masingmasing individu secara primer tidak ditentukan secara sosial struktural, melainkan lebih merupakan hasil pengaruh jangka pendek dan jangka panjang terhadap sang individu (Agustino 2009).

Selanjutnya Angus Campbell, Gerald Gurin dan Warren dari Institute for Social Research (1954), mengembangkan konsep model penjelasan psikologi sosial atas perilaku pemilihan dalam kaitannya dengan pemilihan presiden Amerika Syarikat tahun 1948 dan 1952 (Campbell et al.: The Voter Decides, 1954). Keputusannya, beberapa tahun kemudian terbitlah karya utama para pengkaji pemilihan umum dari Ann Arbor iaitu The
American Voter (Cambell et al. 1960). Untuk menguji dan menyempurnakan konsep awal mereka, maka Campbell melakukan tinjauan terhadap pemilih yang sama, sebelum dan sesudah pemilihan presiden tersebut. Tinjauan tersebut dilakukan di seluruh negeri dengan responden yang diambil secara acak. Sehingga mereka pertama kali berhasil membuat kesimpulan atas perilaku pemilih di seluruh Amerika Serikat.

Pendekatan psikologi sosial berusaha untuk menerangkan faktor-faktor apa saja yang mempengaruhi keputusan pemilih dalam jangka pendek atau keputusan yang diambil dalam masa yang singkat. Pendekatan ini berusaha menjelaskan melalui tiga faktor determinan iaitu; (1) identifikasi partai , (2) orientasi isu/tema, dan (3) identifikasi calon. Selain itu, terdapat faktor-faktor lainnya yang sudah ada lebih dulu iaitu keanggotaan dalam kelompok sosial tertentu, yang dianggap memberi pengaruh langsung terhadap perilaku pemilihan (Roth 2008; Agustino 2009).

Selain pendekatan tersebut di atas, salah satu teori klasik pendekatan rational-choice yang tidak hanya terbatas bagi kajian pemilih pada pemilihan umum ialah teori ekonomi Anthony Downs tentang demokrasi (Downs 1957). Melalui deskripsi Downs tentang homo economicus, beliau menjadi orang yang pertama dan paling konsisten mengambil jarak dari dasar penjelasan yang dimulakan oleh Columbia School dan Michigan School. Menurut Downs (1968), pemilih yang rasional hanya menurut kepentingan diri sendiri atau kalaupun tidak, ia akan sentiasa mendahulukan diri sendiri di atas kepentingan orang lain. Ini disebut juga dengan self-interest axiom. Walaupun menurut Downs, tidak semua orang merupakan orang yang egois bahkan dalam politik sekalipun.

Kecenderungan manusia bertindak egois terutama oleh karena mereka ingin mengoptimalkan kesejahteraan materi mereka, iaitu penghasilan atau harta benda mereka. Jika hal ini diterapkan kepada perilaku pemilih, maka ini bererti bahawa pemilih yang rasional 
akan memilih partai yang paling menjanjikan keuntungan bagi dirinya. Pemilih rasional tidak terlalu tertarik dengan konsep politik sebuah partai, melainkan kepada keuntungan terbesar yang dapat diperoleh apabila partai ini menduduki pemerintahan dibandingkan dengan partai lain. Untuk dapat memperkirakan dan menghitung keuntungan tersebut, yang diistilahkan oleh Downs sebagai 'utility maximation', maka pemilih harus mendapatkan informasi yang lengkap tentang aktiviti partaipartai di masa lalu dan apa yang mungkin dilakukan oleh partai-partai di masa mendatang.

Perspektif tersebut di atas menjadi permasalahan sesungguhnya teori Downs. Dengan adanya informasi yang lengkap, alternatif-alternatif pilihan lebih mudah untuk dirumuskan. Partai yang akan dipilih ialah partai yang menawarkan keuntungan terbesar apabila partai tersebut berkuasa. Bentuk pemerintahan demokrati yang pada dasarnya dinilai positif, menjadi alasan Downs untuk memasukkan nilai penglibatan jangka panjang dalam teori tersebut.

Menurut Downs (1957), seorang pemilih umumnya tidak memiliki informasi yang baik di bidang politik, oleh karena hasil yang diperoleh dari informasi tersebut biasanya tidak seimbang dengan pengorbanan yang diberikan, sehingga bagi mereka ini tidaklah rasional. Tingginya tahap penglibatan pada pemilihan umum, walaupun pemilih memiliki tahap informasi yang rendah, tetap tidak dapat diterangkan dalam teori ini. Namun teori Downs dapat membantu menjelaskan kemunduran tahap penglibatan pemilih pada tahun 1980-1990 yang terjadi di Jerman pada masa tersebut.

Dasar pemikiran Downs (1957) dan Keys (1966) dikembangkan lebih lanjut oleh Morris P. Fiorina (1981) dalam model keputusan pemilihan umum tinjauan kembali. Dalam model ini, tampak bahawa teori perilaku pemilihan yang rasional dan pendekatan psikologi sosial, untuk menjelaskan perilaku pemilih pada pemilihan umum dapat digabungkan dengan baik. Dasar pemikiran Fiorina tidak hanya mempertimbangkan pemilihan tinjauan kembali dan prospektif (Keys \& Downs), namun juga pembinaan identifikasi partai yang merupakan jantung model Ann-Arbor. Oleh itu, Fiorina tidak hanya membedakan antara masa lalu dan masa depan dalam komponen pilihan rasional (pilihan rasional), melainkan membagi identifikasi partai (PI) ke dalam identifikasi partai (PI) masa lalu dan identifikasi partai (PI) masa sekarang. Model tersebut merupakan pengembangan lebih lanjut dari model Key (1966) dan model Downs (1957), yang elemen intinya terdiri atas keputusan pemilihan umum tradisional-tinjauan kembali dan prospektif (Fiorina 1981).

Menurut Brennan dan Lomasky, keputusan untuk memilih/memberikan suara dapat difahami sebagai pernyataan minat/ keinginan yang mendalam untuk ikut ambil bahagian dalam tindakan memilih itu sendiri (intrinsik). Elemen-elemen pusat perilaku pemilih rasional juga dapat ditunjukkan melalui sebuah analisis singkat terhadap pemilihan umum. Analisis orientasi isu/tema yang diangkat dalam kampanye, merupakan masalah terpenting yang perlu mendapat perhatian khusus dari para pemilih. Pendekatan pilihan rasional juga seharusnya membantu kita untuk memahami perilaku pemilu yang terperinci.

Dalam konteks Indonesia, pemilihan umum dan pemilihan kepala daerah yang sudah terlaksana sejak 2004 hingga sekarang ini, kecenderungan perilaku pemilih juga mencerminkan adanya pola pilihan rasional (pilihan rasional) terhadap obyek undian iaitu partai politik, calon presiden, calon gubernur, calon parlemen, dan walikota/bupati. Kecenderungan perilaku politik yang ada bahkan menjurus kepada pola transaksi politik, dimana para pemilih akan memilih objek pilihan tertentu, sekiranya para pemilih mendapatkan keuntungan ekonomi bagi dirinya, kelompok, dan lingkungan sosialnya (Agustino 2009).

\section{PENUTUP}

Demikian beberapa hasil kajian dan paparan yang dapat dikemukakan, berkaitan dengan prediktor perilaku pemilih pada 
pemilihan umum kepala daerah (Pemilukada). Prediktor perilaku pemilih pada pemilukada tersebut mencakup faktor sosiologis, faktor psikologis, faktor rational choice, dan beberapa faktor lain yang terkait dengan hasil penelitian dan kajian pada pelaksanaan pemilihan umum di beberapa negara, dan pelaksanaan pemilihan di negara bagian dan pemilukada di Indonesia, sejak tahun 2005 hingga saat ini.

\section{DAFTAR RUJUKAN}

Abdullah, Rozali. 2005. Pelaksanaan Oronomi Luas dengan Pemilihan Kepala Daerah Secara Langsung. Jakarta: Raja Grafindo Persada.

Adam, James F., Merrill, Samuel., dan Grofman, Bernar, 2005. A. Unified Theory of Party Competition: A CrossNational Analysis Integrating Spatial and Behavioral Factors. Cambridges, Cambridges University Press.

Agustino, Leo. 2009. Pilkada dan Dinamika Politik Lokal. Yogyakarta: Pustaka Pelajar.

Ajzen, Icek. 1987. From Intention to Action: A Theory of Planned Behavior. Dalam Action-control: From Cognition to Behavior. J. Kuhland dan J. Beekman. Heidelberg: Springer.

Ajzen, Icek. 1988. Attitude, Personality and Behavior. Milton Keynes: Open University Press.

Alamsyah, 2011. Dinamika Politik Pilkades di Era Otonomi Daerah (Studi tentang relasi politik calon kepala desa dengan para pemilih Pilkades) Jurnal Tamanpraja Volume 1 Edisi 1, Juni 2011 STPDN Bandung.

Almond, Gabriel A., Verba Sidney. 1990. Budaya Politik, Tingkah Laku Politik dan Demokrasi di Lima Negara. Jakarta: Bina Aksara.

Azwar, Saifuddin. 2007. Sikap Manusia; Teori dan Pengukurannya. Edisi ke 2. Yogyakarta: Pustaka Pelajar.
Barner, Barry Carol and Robert Rosenwein. 1985. Psychological Perspectives on Politics. New Jersey: Prentice-Hall, Inc. Englewood Cliffs.

Baron, R.A., Byrne, D. 2004. Psikologi Sosial. Jilid 1 dan 2, Edisi kesepuluh. Alih bahasa: Ratna Juwita dkk. Jakarta: Erlangga.

Bartels, Lerry M. 2008. The Studi of Electoral Behavior. Departemen of Politics and Woodrow Wilson School of Piblic and International Affairs, Princeton University

Berman, David R. 1986. Voters, Candidates, and Issues in the Progressive Era: An Analysis of the 1912 Presidential Election in Arizona. Social Science Quarterly (Univ. Of Texax Pres) Vol. 67 Issu 2, p.255

Bone, Hugh A. \& Austin Ranney. 1981. Political and Voters. New York. McGraw- Hill. Book Company

Books, John W. and Charles L. Prysby. 1991. Political Behavior and the Local Context. Two edition. New York: Praeger.

Budiardjo, Mirian. 1998. Partisipasi dan Partai Politik. Jakarta: Yayasan Obor Indonesia.

Danim, Sudarwan. 2004. Metode Penelitian untuk Ilmu-Ilmu Prilaku; Acuan dasar bagi mahasiswa Program Sarjana dan Peneliti Pemula. Jakarta: Bumi Aksara.

Dowdding, Keith M. 1991. Rational Choice and Political Power. Brookfeild: Edward Elgar Publishing Company

Dodi Haryadi, Ahmad. 2012. Demokrasi Lokal: Evaluasi Pemilukada di Indonesia. Jakarta: Konpress

Duverger, Maurice. 2007. Sosiologi Politik. Terjemahan: Daniel Dhakidae. Jakarta: Raja Grafindo Persada.

Firmansyah. 2004. Peran Ilmu Marketing dalam Dunia Politik: Menuju Marketing 
Politik di Indonesia. Jurnal Manajemen Usahawan Indonesia No. 01/TH.XXXI. P. 3-11

Gaffar, Affan. 1992. Javanesse Voters, A Case Study of Election Under A Hegemony Party System. Yogyakarta: Gadjah Mada University Press.

Haris, Andi. 2006. Pilkada dan Budaya Politik Lokal. FAJAR, 20 April 2006 Makassar: Harian Pagi Fajar.

Hubtington, Samuel P. dan Nelson, Joan. 1994. Partisipasi Politik di Negara Berkembang. Jakarta: Rineka cipta.

Joseph M. Fernando, Zulkarnain Abdul Rahman, dan Suffian Mansor (Ed.). 2011. Pilihan Raya Umum Malaysia Ke-12, Isu dan Pola Pengundian. Kuala Lumpur: Universiti Malaya

Kavanagh, Dennis. 1983. Political Science and Political Behavior. London: George Allen and Unwin.

Lembaga Survei Indonesia. 2004. Potret Buram Pemilih dan Peran Civil Society menjelang Pemilu 2004. Jakarta: Lembaga Survei Indonesia

Ma'rof Redzuan. 2001. Psikologi Sosial. Serdang: University Putra Malaysia.

Matulessy, Andik. 2005. Psikologi Politik. Surabaya: Srikandi

Mujani, Saiful and R. William Liddle. 2010. Personalities, Parties and Voters. Journal of Democracy. Volume 21, Number 2

Muluk, Hamdi. 2010. Mozaik Psikologi Politik Indonesia. Jakarta: Rajawali Pers

Nannestad, Peter. 1998. Voting and Political Attitudes in Denmark: A Study of the 1994 Election. The American Political Science Review, 92:2

Newman, B.I. dan Sheeth, J.N. 1985. A Model of Primary Voter Behavior. Journal of Consumer Research: P. 178-187

Nursal, Adman. 2004. Political Marketing: Strategi memenangkan Pemilu: sebuah pendekatan baru kampanye Pemilihan $D P R, \quad D P D, \quad$ Presiden. Jakarta: Gramedia Pustaka Utama

O"Cass, A. 2001. Political Marketing: an Investigation of the political market orientation in Australian politics. European Journal of Marketing. No. 35. P. 1003-1025

Pamungkas, Sigit. 2009. Pemilu, Perilaku Pemilih dan Kepartaian. Yogyakarta: Institute for Democracy and Welfarism

Qodari, Muhamad. 2008. Partisipasi Rendah, Lemahnya Proses Administrasi. Majalah PIGUR, Edisi XXII. Jakarta: Panca Wira Karsa.

Rozmi Ismail. 2011. Psikologi Sosial. Bangi: Universiti Kebangsaan Malaysia

Roth, Dieter. 2008. Studi Pemilu Empiris; Sumber, Teori-teori, Instrumen dan Metode. Penterjemah: Danise Matindas. Jakarta: Friedrich-Naumann-Stiftung feur die Freiheit

Sanit, Arbi. 1997. Partai, Pemilu dan Demokrasi. Yogyakarta: Pustaka Pelajar

Sastroatmodjo, S. 1995. Perilaku Politik, Semarang: IKIP Semarang Press.

Siti Zuhro, R. (Ed.). 2009. Demokrasi Lokal, Peran Aktor Dalam Demokratisasi. Yogyakarta: Ombak

Sugiono, Arif. 2005. Faktor yang Mempengaruhi Perilaku Pemilih dalam Pilkada: Perspektif Political Marketing. Jurnal Manajemen Usahawan Indonesia. No. 05/TH.XXXI V Mei 2005. LMPE Universitas Indonesia

Surbakti, Ramlan. 1992. Pemilihan pada Pemilu 1992. Antara Kendala dan Peluang. Makalah pada Seminar Nasional IX AIPI, Surabaya, 6-8 Agustus 1992.

Suryatna, U. 2011. Pengaruh Terpaan Media Iklan Politik Terhadap Perilaku Pemilih Pemula. Jurnal Sosial Humaniora 2(2): 134-144 